\title{
ラットにおけるプロピオン酸トリグリセリドの 脂質代謝に及ほす影響
}

\author{
田代 力 $\exists^{*}$, 新 田理 恵*, 松 山 惊* \\ 新 井千 秋**, 矢 嶋 瑞 夫**, 清 澤 功* \\ * 玉川大学農学部 \\ **アサマ化成株式会社
}

\section{Effects of Propionyl Triglyceride on Lipid Metabolism in Rats}

\author{
Kayo TASHIRO, ${ }^{*}$ Rie NITTA, ${ }^{*}$ Jun MATSUYAMA, ${ }^{*}$ \\ Chiaki ARAI, ${ }^{* *}$ Mizuo YAJIMA** and Isao KIYOSAWA* \\ * Department of Agriculture, Tamagawa University, Machida, Tokyo 194 \\ ** Asama Kasei Co. Ltd., Chuo-ku, Tokyo 103
}

\begin{abstract}
J. Jpn. Soc. Nutr. Food Sci., 50, 417 422 (1997)
The effects of dietary propionyl triglyceride (PTG) on body weight, serum and hepatic lipids, and the organic acid level in cecum and feces, were investigated in rats. The body weight gain over 14 days in the 5\% PTG group was lowest upon comparison with those of the PTG-free (control) and 1\% and 3\% PTG groups. However, there were no significant differences in food efficiency ratio among the control and PTG groups. The serum cholesterol and triglyceride concentrations in the PTG groups were lower than those in the control group, but the serum HDL-cholesterol concentration was almost the same among the various groups. The contents of hepatic total lipids, total cholesterol, and triglyceride in the PTG groups were lower than those in the control group, but the phospholipid content was higher in the PTG groups. The fecal excretion of neutral steroid was greater in the PTG groups than in the control group. There was little difference in the amounts of organic acids such as acetic, propionic, and butyric acids, except for lactic acid, in the cecal contents and feces among the groups.
\end{abstract}

Key Words propionyl triglyceride, cholesterol, phospholipid, triglyceride.

(Received December 20, 1996)

プロピオン酸は, 哺乳動物の大腸内容物または䔬中に 見いだされる奇数鎖脂肪酸であり, 食物瀻維, ムコ多糖 などの腸内発酵によって生成される。このため, 酢酸, 酪酸などの偶数鎖脂肪酸とともに, その生理的役割が注 目されている゙。

Chen ら²)によると, ラットにプロピオン酸ナトリウ ムーコレステロール添加食餌を与えると, 血清および肝コ レステロール濃度が著しく隇少する。ブタに $5 \%$ プロピ オン酸添加食䬲を与えても, 血獎コレステロール濃度が 低下することが報告されている3”。また,ラットの胃およ び盲腸にプロピオン酸およびそのナトリウム塩を注入す ると, 血漿コレステロールが低下する゙)。さらに, プロピ

* 个 194 東京都町田市玉川学園 6-1-1

** $₹ 103$ 東京都中央区日本橋小伝馬町 20-3
オン酸カルシウム添加食餌を与えた場合, ミクロソーム のヒドロキシメチルグルタリル-CoA (HMG-CoA) レダ クターゼ活性がわずかに低下し5), ラット肝細胞におけ る $\left[1-{ }^{14} \mathrm{C}\right]$ 酢酸, $\left[2-{ }^{14} \mathrm{C}\right]$ メバロン酸および ${ }^{3} \mathrm{H}_{2} \mathrm{O}$ のコ レステロールおよび脂肪酸への導入をプロピオン酸が抑 制することが報告されている6)。

一方, 消化管におけるプロピオン酸などの短鎖脂肪酸 の役割として, 回腸, 結腸などの螦動運動への影響7), 粘 膜上皮細胞の増殖促進などが知られている ${ }^{11}$ 。また, 食䬦 性プロピオン酸はプロイラー種ヒヨコのサルモネラ菌の 増殖抑制にも効果があり ${ }^{8)}$ ，消化管内における有害菌の 増殖抑制作用も期待できる。しかし, この脂肪酸は強い 刺激臭を有するので, 食物などに多量添加することはで きないし，加工上にも問題がある。 そこで, プロピオン酸をほとんど刺激臭のないプロピ 
オン酸トリグリセリド (PTG) の形にすると, 動物への 多量摄取が可能になり，動物の消化管内におけるサルモ ネラ菌などの有害菌の増殖抑制が考えられる。さらに， 酢酸，酪酸などとは異なった奇数短鎖脂肪酸としての生 理効果が期待される。その反面，奇数短鎖脂肪酸の多量 摄取による代謝上の問題も考慮する必要がある。このた め, 本研究では PTG 添加飼料で飼育したラットの発育 状態を観察し, PTG の脂質代謝への影響について調べた ので報告する。

\section{実 験 方 法}

\section{1. プロピオン酸トリグリセリドの調製}

無水プロピオン酸（東京化成工業侏製）とグリセロー ル(昭和化学(俐製) を加熱 $\left(120 \sim 130^{\circ} \mathrm{C}\right)$, 擋汼し, 約 9 時間環流反応した後, 真空蒸留 $\left(90 \sim 165^{\circ} \mathrm{C}\right)$ した。この 残留物に窒素ガスを吹き込んで脱臭し，活性炭を残留物 に対して $2 \%$ 添加し, 加温, 擋汼して脱色し, プロピオン 酸トリグリセリド（PTG）を得た。

使用したPTG の純度は，エステル価法では $99.1 \%$, ガスクロマトグラフィーによる分析では $98.9 \%$ でっ

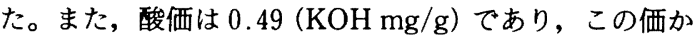
ら算出した遊離プロピオン酸含量は $0.06 \%$ あったたガ スクロマトグラフィーでは, PTG ピークの直後に原料 の無水プロピオン酸のピークが現れたが，このピーク面 積は全面積の $0.87 \%$ あった。なお，ガスクロマトグラ フィーは次の条件で行った。ガラスカラム, $1.5 \mathrm{~m} \times 3.2$ $\mathrm{mm}$; 支持体, Diasolid LP ; 液相, SE-30 $3 \%$ ：気化室 温度, $120^{\circ} \mathrm{C}$ ：カラム槽温度, $80 \sim 270^{\circ} \mathrm{C}\left(4^{\circ} \mathrm{C} / \mathrm{min}\right)$ ：キャ リアーガス, 窒素 $40 \mathrm{~m} / \mathrm{min}$ 。

\section{2. 実験動物および飼育条件}

3 週齢の SD 系雄ラット（日本材料生物センター侏上 り購入) をケージに個体別に収容し，12 時間サイクルの 明暗の下で飼育した $\left(23 \pm 1^{\circ} \mathrm{C}\right)$ 。予備飼育は対照飼料で 4 日間行い,ついで各試験飼料で 14 日間飼育した。この 間，飼料および水は自由摂取とした。

䔬は毎日採取し, 実験開始日から 7 日までの䔬をまと めて第 1 週䔬試料, 次の 8 日から 14 日までの䶞を第 2 週䔬試料とし, それらを凍結乾燥後粉末化して脂質分析 試料とした。有機酸分析用の䔬はー $20^{\circ} \mathrm{C} て ゙$ 涷結保存し た。

飼育最終日 (14 日後)には，12 時間の絶食後エーテル 麻酔下で開腹し，下大静脈より採血し，肝臓および盲腸 を摘出した。肝臓は凍結乾燥後粉砕して分析試料とし, 盲腸の内容物は取り出した後, 分析に供するまで直ち にー20 $20^{\circ} \mathrm{C}$ で保存した。なお, 試験食による飼育の 7 日目 には午前 10 時に尾静脈より採血し,その血清について脂 質分析を行った。
Table 1. Compositions of control and propionyl triglyceride diets $(\mathrm{g} / 100 \mathrm{~g})$.

\begin{tabular}{lrrrr}
\hline \hline \multirow{2}{*}{ Material } & \multirow{3}{*}{ Control } & \multicolumn{3}{c}{ PTG } \\
\cline { 3 - 5 } & & \multicolumn{1}{c}{$1 \%$} & \multicolumn{1}{c}{$3 \%$} & \multicolumn{1}{c}{$5 \%$} \\
\hline Casein & 20.0 & 20.0 & 20.0 & 20.0 \\
Corn oil & 10.0 & 9.0 & 7.0 & 5.0 \\
PTG & 0.0 & 1.0 & 3.0 & 5.0 \\
Corn starch & 49.5 & 49.5 & 49.5 & 49.5 \\
Sucrose & 10.0 & 10.0 & 10.0 & 10.0 \\
Cellulose & 5.0 & 5.0 & 5.0 & 5.0 \\
Mineral mixture & 3.5 & 3.5 & 3.5 & 3.5 \\
Vitamin mixture & 2.0 & 2.0 & 2.0 & 2.0 \\
\hline \hline
\end{tabular}

PTG, propionyl triglyceride. Each mixture of mineral and vitamin was identical with AIN-76 mixture. ${ }^{9)}$

\section{3. 飼料組成}

対照飼料および PTG 添加飼料の組成を Table 1 に示 した。飼料の PTG 含量は $1.0,3.0$ および $5.0 \%$ と, 全 脂質含量をコーン油で調整して $10 \%$ とした。なお，ラッ トは各群を 5 匹とした。

\section{4. 血清および肝脿の脂質分析}

血清脂質の測定は，市販の試薬キットを用いて行い， 総コレステロール (デタミナーTC555)，トリアシルグ リセロール（デタミナーTG-S555）おるひひ遊離脂肪酸 （デタミナーNEFA）を定量した。さらに，HDL-コレス テロールの測定は，デタミナーHDL を用い，HDL 以外 のリポタンパク質を沈澱, 除去した後,デタミナー TC555により定量した。なおここれらの定量に用いた キットは協和メデックス琍のものである。

肝臟は，まず凍結乾燥物の脂質を Folch らの方法 ${ }^{10)} に$ より抽出し，全脂質量を重量法によって定量した。ま た，この粗脂質抽出液の総コレステロール（デタミナー $\mathrm{TC} 555$ ), リン脂質（リン脂質テストワコー，和光純薬 梸）およびトリグリセリド（トリグリセリドテストワ コー, 和光純薬(俐) を市販の試薬キットを用いて定量し た。

\section{5. 黄および盲腸内容物の脂質と有機酸分析}

第 1 週䔬試料および第 2 週䔬試料の䔬凍結乾燥物から Folch らの方法 ${ }^{10)} に よ り$ 脂質を抽出した。この抽出液の 総脂質を重量法により測定し, 中性ステロイド (デタミ ナーTC5, 協和メデックス(保) および酸性ステロイド （エンザバイル・2，第一化学薬品侏）を市販キットを用 いて定量した。これらの定量値から，各脂質の黄中への 1 日当りの排泄量を求めた。

また, 試験食期間の最終日（14日目）に採取した䔬お よび盲腸内容物の有機酸（乳酸, 酢酸, プロピオン酸, 酪酸)を測定した。測定にあたり，各試料は Morishitaら 
Table 2. Body weight gain, food intake, fecal weight, and liver weight in the rats fed on control and propionyl triglyceride diets for 2 weeks.

\begin{tabular}{lcccc}
\hline \hline & Control & \multicolumn{3}{c}{ PTG $^{1}$} \\
\cline { 2 - 4 } & (PTG free) & $1 \%$ & $3 \%$ & $5 \%$ \\
\hline Initial weight (g) & $77 \pm 3$ & $81 \pm 2$ & $80 \pm 3$ & $82 \pm 7$ \\
Body weight gain (BW, g) & $105 \pm 1^{\mathrm{a}}$ & $102 \pm 8^{\mathrm{a}}$ & $98 \pm 4^{\mathrm{a}}$ & $87 \pm 7^{\mathrm{b}}$ \\
Food intake (g/day) & $14.9 \pm 0.2^{\mathrm{a}}$ & $14.4 \pm 1.0^{\mathrm{a}}$ & $14.0 \pm 0.9^{\mathrm{a}}$ & $12.4 \pm 0.7^{\mathrm{b}}$ \\
Fecal weight (g/day) & $1.1 \pm 0.0^{\mathrm{a}}$ & $1.1 \pm 0.1^{\mathrm{a}}$ & $1.1 \pm 0.0^{\mathrm{a}}$ & $0.9 \pm 0.1^{\mathrm{b}}$ \\
Food efficiency ratio $^{2}$ & $0.51 \pm 0.01^{\mathrm{a}}$ & $0.48 \pm 0.02^{\mathrm{b}}$ & $0.49 \pm 0.01^{\mathrm{b}}$ & $0.49 \pm 0.01^{\mathrm{b}}$ \\
Liver weight (LW, g) & $6.8 \pm 0.1^{\mathrm{a}}$ & $6.5 \pm 0.3^{\mathrm{ab}}$ & $6.4 \pm 0.4^{\mathrm{ab}}$ & $6.0 \pm 0.4^{\mathrm{b}}$ \\
LW/BW (\%) & $3.7 \pm 0.0$ & $3.7 \pm 0.1$ & $3.6 \pm 0.1$ & $3.7 \pm 0.1$ \\
\hline \hline
\end{tabular}

${ }^{1}$ Propionyl triglyceride. ${ }^{2}$ Body weight gain/food intake. Each value represents as the means \pm SD, $n=5$. Values having the different superscript letters within rows are significantly different, $p<0.05$.

の方法 ${ }^{11} に よ り$ 有機酸を抽出した後, 抽出液についてク ロマトグラフィー（島津高速液体クロマトグラフ有機酸 分析システム)を行い, 各有機酸を測定した。

\section{6. 統計処理}

実験データは平均値士標準偏差 (SE) で表した。また, ANOVA (analysis of variance) 統計解析プログラムを 用いて一次検定を行った後, Duncan の多重検定法によ り各群間の有意差 $(p<0.05)$ を判定した。

\section{実験結果および考察}

\section{1. 体重増加およひ肝重量}

PTG 無添加（対照）および PTG1〜 5\%添加飼料で 14 日間飼育した各ラット群の体重增加量および肝重量を Table 2 に示した。これによると, 14 日後のラットの体 重增加量および肝重量は, PTG 添加量が高い群ほど低値 を示した。しかし, 対照群, 1\%および3\% PTG 群の間 では有意差が認められず，5\% PTG 群のみが有意に低 かった。しかし, 肝重量の体重に占める割合は, 各群間 でほとんど差がなかった。

この飼育期間における各群の体重增加曲線を Fig. 1 に示した。対照群の体重はほほ直線的に増加した。しか し, とくに $5 \%$ PTG 群は実験開始後 3 日間体重の増加が ほとんどなかった。これは, 対照飼料から試験飼料に切 り換えた際, PTG 添加飼料に順応できるまで摄取量が 隇少し, それが体重増加に影響したものと考えられる。 $5 \%$ PTG 飼料による 3 日以降の体重增加は, ほとんど対 照群と同じであった。PTG はプロピオン酸 (PA) と異 なり,プロピオン酸に特異的な刺激臭はほとんどなかっ たが，苦味を呈したので，これがラットの最初の摂取量 に影響したものと考えられる。

\section{2. 血海脂質}

各ラット群の実験開始 7 日および 14 日後の血清脂質 濃度をTable 3 に示した。7日後の総コレステロール

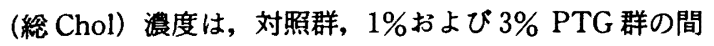

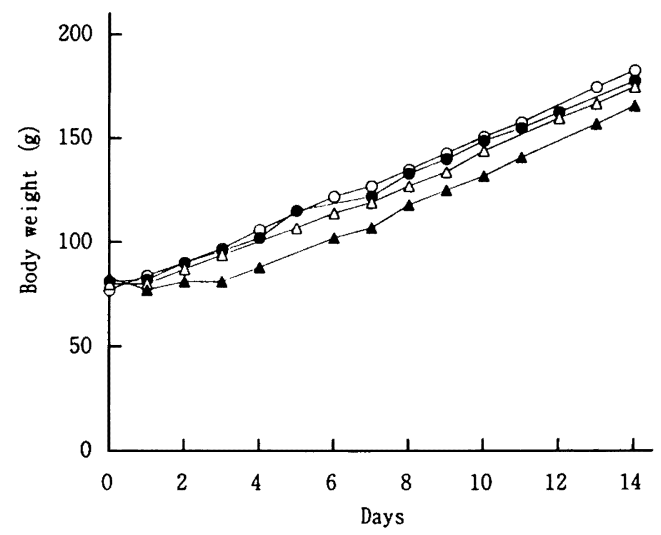

Fig. 1. Body weight in the rats fed on control and propionyl triglyceride diets for 14 days.

○, Control (PTG-free) : •, 1\% PTG : $\triangle, \quad 3 \%$ PTG : $₫, 5 \%$ PTG diet groups. Each point represents the average body weight of 5 rats.

で有意差は認められなかったが, 5\% PTG 群が低値を示 した。しかし，14 日後では対照群と PTG 群の間で有意 差が認められたが, PTG 群間では有意差はなかった。

Chen ら ${ }^{2)}$ は $0.5 \%$ プロピオン酸ナトリウム $(\mathrm{NaPA})$ $+0.3 \% \mathrm{Chol}$ 添加飼料を SD 系雄ラット $(250 \sim 300 \mathrm{~g})$ に与えたところ, 血清総 Chol 濃度が対照飼料 (PA およ び Chol 無添加）に比較して有意に低下することを認め た。しかし，対照飼料と $0.5 \%$ PA または $0.3 \%$ Chol 添 加飼料の間ではほとんど差が認められなかった。また, Levrat ら5)によると, ウイスター系雄ラット $(\sim 170 \mathrm{~g})$ に2.5\%プロピオン酸カルシウム $(\mathrm{CaPA})$ 添加飼料を与 えたところ, 血㢡 Chol 濃度は対照ラットに比較して有 意に低下することはなかった。本実験では，これらの実 験と異なり, 飼料に Chol を添加しなかったが,ラットの 血清総 Chol 濃度は PTG 添加飼料によって低下した。著 
Table 3. Serum lipid concentrations at the day 7 and 14 in the rats fed on control and propionyl triglyceride diets.

\begin{tabular}{llcccc}
\hline \hline & Serum & Control & \multicolumn{3}{c}{ PTG } \\
\cline { 3 - 5 } & & $($ PTG free) & $1 \%$ & $3 \%$ & $5 \%$ \\
\hline Day 7 & Total cholesterol $(\mathrm{mg} / \mathrm{dl})$ & $67 \pm 9^{\mathrm{a}}$ & $59 \pm 5^{\mathrm{a}}$ & $66 \pm 5^{\mathrm{a}}$ & $41 \pm 4^{\mathrm{b}}$ \\
& HDL-cholesterol $(\mathrm{mg} / \mathrm{dl})$ & $41 \pm 3^{\mathrm{a}}$ & $53 \pm 4^{\mathrm{b}}$ & $44 \pm 4^{\mathrm{ab}}$ & $41 \pm 5^{\mathrm{a}}$ \\
& Triglyceride $(\mathrm{mg} / \mathrm{dl})$ & $50 \pm 6^{\mathrm{a}}$ & $71 \pm 13^{\mathrm{ab}}$ & $80 \pm 18^{\mathrm{b}}$ & $64 \pm 17^{\mathrm{ab}}$ \\
& Free fatty acid $(\mu \mathrm{Eq} / l)$ & $684 \pm 62$ & $693 \pm 27$ & $679 \pm 17$ & $603 \pm 21$ \\
Day 14 & $80 \pm 16^{\mathrm{b}}$ & $49 \pm 4^{\mathrm{a}}$ & $53 \pm 3^{\mathrm{a}}$ & $55 \pm 4^{\mathrm{a}}$ \\
& Total cholesterol $(\mathrm{mg} / \mathrm{dl})$ & $45 \pm 3$ & $46 \pm 1$ & $49 \pm 3$ & $49 \pm 8$ \\
& HDL-cholesterol $(\mathrm{mg} / \mathrm{dl})$ & $172 \pm 15^{\mathrm{a}}$ & $151 \pm 28^{\mathrm{ab}}$ & $138 \pm 11^{\mathrm{ab}}$ & $126 \pm 24^{\mathrm{b}}$ \\
& Triglyceride $(\mathrm{mg} / \mathrm{dl})$ & $847 \pm 166$ & $825 \pm 158$ & $862 \pm 175$ & $742 \pm 30$ \\
& Free fatty acid $(\mu \mathrm{Eq} / l)$ & &
\end{tabular}

PTG, propionyl triglyceride. Each value represents as the means \pm SD, $n=5$. Values having the different superscript letters within rows are significantly different, $p<0.05$.

者らの結果とそれら報告との相違は, 飼料組成（とくに 脂質, 繊維), PA の形態, 実験開始時のラット体重など の相違がもたらしたものと考えられる。

Ebihara ら ${ }^{4)}$ はラットの胃および盲腸に直接 PA また は NaPA を注入したところ，PA 注入の場合のみがカゼ イン飼料による血槳 Chol 濃度の上昇を抑制したと報告 している。したがって, 著者らの PTG を飼料へ直接添 加する場合と $\mathrm{NaPA}$ または $\mathrm{CaPA}$ の飼料添加の場合で は, 血清総 $\mathrm{Chol}$ 濃度への影響が異なるのは, それら PA の形態により消化管における PA の吸収性が異なる可能 性が推察される。

血清 HDL-コレステロール（HDL-Chol）濃度は，1\% PTG 群の試験開始 7 日後を除いて各群間でいずれも有 意差は認められなかった。Kishimotoら ${ }^{12)}$ は NaPA を ラットに静脈注射し, 血清 HDL-Chol 濃度の変動を観察 している。それによると, NaPA $1 \mathrm{mg}$ 投与後 1 時間にお いて生理食塩水を投与した対照より有意に高かったが, その後有意差は認められなかった。本実験において試験 開始 7 日後の $1 \%$ PTG 群の血清 HDL-Chol 濃度が高 かった点について, PTG 添加量による影響なのか, 採血
時間による影響なのかさらに検討が必要である。 血清トリグリセリド (TG) 濃度は, 試験開始 7 日およ び 14 日後における PTG 添加群間では有意の差は認め られなかった。また遊離脂肪酸濃度は, 対照群と各 PTG 群間で有意差はなかったが，5\%添加群では低值を示し た。これらの点から，5\% PTG 添加群ではとくに血清総 コレステロール濃度は低下し，HDL コレステロール濃 度は対照群と有意差がないので，5\% PTG 群の VLDL または LDL 濃度は低下していることが推察される。

\section{3. 肝臟脂質}

各ラット群の試験開始 14 日後における肝臓 $1 \mathrm{~g}$ 当り の全脂質，総 Chol，TG およびリン脂質（PL）含量を Table 4 に示した。全脂質および総 Chol 含量は，5\% PTG 群のみが他の群に比較して有意に低值を示した。 また，PTG 群の TG 含量は，対照群と 1\% PTG 群，ま たはPTG 群間では有意差はなかったが，対照群と $3 \%$ および5\% PTG 群では有意差が認められた。さらに, 肝 リン脂質含量は各群間で有意差は認められなかった。

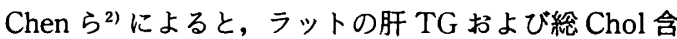
量は， $0.5 \% \mathrm{PA}$ 添加飼料では対照飼料（PA 無添加）と

Table 4. Lipid contents in the liver of rats fed on control and propionyl triglyceride diets for 14 days.

\begin{tabular}{clcccc}
\hline \hline \multirow{2}{*}{ Liver } & & Control & \multicolumn{3}{c}{ PTG } \\
\cline { 3 - 5 } & & $($ PTG free $)$ & $1 \%$ & $3 \%$ & $5 \%$ \\
\hline Total lipid & $(\mathrm{mg} / \mathrm{g})$ & $99 \pm 2^{\mathrm{a}}$ & $98 \pm 3^{\mathrm{a}}$ & $108 \pm 13^{\mathrm{a}}$ & $73 \pm 5^{\mathrm{b}}$ \\
& $(\mathrm{mg} / \mathrm{liver})$ & $673 \pm 11^{\mathrm{a}}$ & $645 \pm 14^{\mathrm{a}}$ & $667 \pm 83^{\mathrm{a}}$ & $448 \pm 47^{\mathrm{b}}$ \\
Total cholesterol & $(\mathrm{mg} / \mathrm{g})$ & $2.6 \pm 0.1^{\mathrm{a}}$ & $2.5 \pm 0.2^{\mathrm{ab}}$ & $2.4 \pm 0.3^{\mathrm{ab}}$ & $2.1 \pm 0.2^{\mathrm{b}}$ \\
& $(\mathrm{mg} /$ liver $)$ & $17.7 \pm 0.8^{\mathrm{a}}$ & $16.0 \pm 2.2^{\mathrm{a}}$ & $15.4 \pm 2.5^{\mathrm{a}}$ & $12.8 \pm 1.6^{\mathrm{b}}$ \\
Triglyceride & $(\mathrm{mg} / \mathrm{g})$ & $40 \pm 2^{\mathrm{b}}$ & $35 \pm 6^{\mathrm{ab}}$ & $28 \pm 4^{\mathrm{a}}$ & $29 \pm 2^{\mathrm{a}}$ \\
& $(\mathrm{mg} /$ liver $)$ & $272 \pm 14^{\mathrm{c}}$ & $230 \pm 24^{\mathrm{b}}$ & $179 \pm 28^{\mathrm{a}}$ & $182 \pm 5^{\mathrm{a}}$ \\
Phospholipid & $(\mathrm{mg} / \mathrm{g})$ & $21 \pm 8$ & $25 \pm 1$ & $29 \pm 2$ & $28 \pm 2$ \\
& $(\mathrm{mg} /$ liver $)$ & $144 \pm 56$ & $160 \pm 4$ & $175 \pm 16$ & $171 \pm 18$ \\
\hline \hline
\end{tabular}

PTG, propionyl triglyceride. Each value represents as the means $\pm \mathrm{SD}, n=5$. Values having the different superscript letters within rows are significantly different, $p<0.05$. 
比較してほとんど差がなかった。しかし，肝のChol およ び TG 含量が $0.3 \%$ Chol 添加飼料では高まり， $0.3 \%$ Chol + 0.5\% PA 飼料では有意に低下した。また， $2.5 \%$ プロピオン酸カルシウム添加飼料で飼育したラットの肝 3-ヒドロキシ-3-メチルグルタリル CoA (HMG-CoA)レ ダクターゼ活性は, プロピオン酸カルシウム無添加飼料 の場合より約 $25 \%$ 低下することが報告されている6)。さ

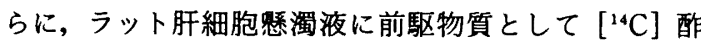
酸, $\left[{ }^{14} \mathrm{C}\right]$ メバロン酸または ${ }^{3} \mathrm{H}_{2} \mathrm{O}$ を添加した際の Chol および脂肪酸生合成における PA の阻害作用が検 討されている5)。それによると，慜濁液中の PA 濃度が $1.0 \mathrm{~mm}$ 以上になると, Chol および脂肪酸生合成が有意 に阻害され， $\left[{ }^{14} \mathrm{C}\right]$ 酢酸以外の前駆物質でも PA による 阻害作用が認められている。本実験では, 肝の PA 濃度お よび HMG-CoAレダクターゼ活性は測定しなかったが, 対照群と PTG 群または PTG 群間における肝 Chol お よびTG 含量に差が生じたのは, 肝に取り込まれた PA による Chol および TG 生合成の阻害作用によることが 考えられる。また, Levrat ら ${ }^{6)}$ の結果では, 2.5\% CaPA 添加でも肝 Chol 含量に顕著な変化が認められなかった のは, 消化管からのその吸収性が低いことが原因と推察 される。

\section{4. 黄の脂質およびステロイド}

各群における第 1 週および第 2 週糞試料の 1 日当りの 全脂質, 中性ステロイドならびに酸性ステロイド排泄量 を Table 5 に示した。全脂質の 1 日平均排泄量は, 第 1 週賈試料では $1 \%$ PTG 群で他の群に比較して高值て あったが,この理由は明らかではない。しかし，3\%およ び5\% PTG 群では対照群より低值であったのは，これ らの群の飼料摂取量が少なかったためと考える。第 2 週 䔬試料でも PTG 群間では同様の傾向を示し,とくに $5 \%$ PTG 群が対照群より有意に低值を示した。

中性ステロイドの 1 日平均排泄量は, 第 1 週䔬試料で は $1 \%$ PTG 群のみが高值を示した。しかし, 第 2 週糞試
料では各群間に有意差は認められなかった。酸性ステロ イドの 1 日平均排泄量も第 1 週および第 2 週の䔬試料に おいて $1 \%$ PTG 添加群が高値を示した。

竹久 ${ }^{13)}$ によると，5\%セルロース添加食（カゼイン $20 \%$, 大豆油 $20 \% ， \alpha$-デンプン $54.9 \%$ などを含む）で ウイスター系雄ラット (8 週齢) を飼育した場合, 䔬への 中性および酸性ステロイドの 1 日平均排泄量はそれぞれ $2,100 \mu \mathrm{g}$ および $3.97 \mathrm{mg}$ (コール酸として約 10.3 $\mu \mathrm{mol})$ である。本実験では, これらの值と比較して中性 ステロイド排泄量は高く,酸性ステロイド排泄量は低い。 これらの相違は, 飼料組成や䔬ステロイドの抽出法およ び定量法が異なるので，十分な検討ができない。さらに， 小田ら ${ }^{14)}$ によると, $1.0 \%$ コーン油, $9.0 \%$ ラド, $1.0 \%$ Chol, $0.25 \%$ コール酸ナトリウム, $5.0 \%$ セルロースなど を含む飼料で SD 系ラットを飼育した場合，糞への中性 および酸性ステロイドの1日平均排泄量はそれぞれ

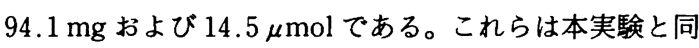
じ方法で測定しているが, いずれも本実験よりも高值で ある。これはChol およびコール酸ナトリウムの飼料へ の添加が影響していると考える。

\section{5. 黄および盲腸内容物の有機酸含量}

試験開始後 14 日目の䔬と盲腸内容物中の乳酸および 短鎖脂肪酸含量を Table 6 に示した。これによると，3\% および $5 \% \mathrm{PTG}$ 群の乳酸以外の短鎖脂肪酸は, 䔬, 盲腸 内容物ともに顕著な差異は認められなかった。佐藤ら ${ }^{15}$ によると，20\%セルロース添加飼料で SD 系雄ラットを 飼育した場合, 盲腸内容物 $1 \mathrm{~g}$ 当り酢酸 $3,161 \mu \mathrm{g}$, プロ ピオン酸 $578.8 \mu \mathrm{g}$ および酪酸 $636.0 \mu \mathrm{g}$ である。本実験 とは飼料内容も異なるので, 佐藤ら ${ }^{15)}$ の結果とこれら有 機酸含量は異なるが，いずれの結果も酢酸が最も高值を 示した。本実験ではPTG を使用しているので, 盲腸な いしは結腸における遊離プロピオン酸濃度の上昇が期待 されたが, 盲腸内容物でととにプロピオン酸濃度の上 昇は認められなかった。

Table 5. Fecal excreation of total lipid, neutral steroids, and acidic steroids during the periods of first week and second week in the rats fed on control and propionyl triglyceride diets.

\begin{tabular}{cccccc}
\hline \hline \multirow{2}{*}{ Period } & \multirow{2}{*}{ Feces } & Control & \multicolumn{3}{c}{ PTG } \\
\cline { 3 - 6 } & & (PTG free) & $1 \%$ & $3 \%$ & $5 \%$ \\
\hline \multirow{2}{*}{ 1st week } & TL (mg/day) & $50 \pm 3^{\mathrm{b}}$ & $60 \pm 5^{\mathrm{c}}$ & $43 \pm 0.1^{\mathrm{ab}}$ & $37 \pm 4^{\mathrm{a}}$ \\
& NS (mg/day) & $7.3 \pm 1.9^{\mathrm{ab}}$ & $29.6 \pm 18.6^{\mathrm{b}}$ & $20.8 \pm 13.6^{\mathrm{ab}}$ & $3.5 \pm 0.6^{\mathrm{a}}$ \\
& AS ( $\mu$ g/day) & $51 \pm 205^{\mathrm{a}}$ & $774 \pm 279^{\mathrm{b}}$ & $157 \pm 55^{\mathrm{a}}$ & $39 \pm 0^{\mathrm{a}}$ \\
\multirow{3}{*}{ 2nd week } & TL (mg/day) & $67 \pm 18^{\mathrm{a}}$ & $81 \pm 12^{\mathrm{a}}$ & $76 \pm 16^{\mathrm{a}}$ & $45 \pm 10^{\mathrm{b}}$ \\
& NS (mg/day) & $5.6 \pm 1.7$ & $8.9 \pm 2.7$ & $8.5 \pm 2.1$ & $7.3 \pm 1.9$ \\
& AS ( $\mu$ g/day) & $55 \pm 8^{\mathrm{a}}$ & $362 \pm 16^{\mathrm{b}}$ & $59 \pm 12^{\mathrm{a}}$ & \\
\hline \hline
\end{tabular}

PTG, propionyl triglyceride; TL, total lipid; NS, neutral steroids; AS, acidic steroids. Each value represents as the means $\pm \mathrm{SD}, n=5$. Values having the different superscript letters within rows are significantly different, $p<$ 0.05 . 
Table 6. Lactic acid and short-chain fatty acid contents at the day 14 in the feces and cecal contents of the rats fed on control and propionyl triglyceride diets.

\begin{tabular}{|c|c|c|c|c|c|}
\hline \multirow{2}{*}{ Sample } & \multirow{2}{*}{$\begin{array}{l}\text { Short-chain } \\
\text { fatty acid }\end{array}$} & \multirow{2}{*}{$\begin{array}{c}\text { Control } \\
\text { (PTG free) }\end{array}$} & \multicolumn{3}{|c|}{ PTG } \\
\hline & & & $1 \%$ & $3 \%$ & $5 \%$ \\
\hline \multicolumn{6}{|c|}{ (mg/g feces) } \\
\hline \multirow[t]{4}{*}{ Feces } & Lactic acid & $0.55 \pm 0.29$ & $0.40 \pm 0.18$ & $0.25 \pm 0.06$ & $0.19 \pm 0.04$ \\
\hline & Acetic acid & $0.86 \pm 0.11$ & $0.80 \pm 0.25$ & $0.80 \pm 0.41$ & $0.83 \pm 0.30$ \\
\hline & Propionic acid & $0.15 \pm 0.06$ & $0.15 \pm 0.08$ & $0.15 \pm 0.05$ & $0.10 \pm 0.01$ \\
\hline & Butyric acid & $\begin{array}{r}0.13 \pm 0.07 \\
(\mathrm{mg} / \mathrm{g}\end{array}$ & $\begin{array}{l}0.16 \pm 0.08 \\
\text { content) }\end{array}$ & $0.19 \pm 0.10$ & $0.16 \pm 0.09$ \\
\hline \multirow{4}{*}{$\begin{array}{l}\text { Cecum } \\
\text { content }\end{array}$} & Lactic acid & $0.07 \pm 0.01$ & $0.08 \pm 0.01$ & $0.08 \pm 0.02$ & $0.07 \pm 0.01$ \\
\hline & Acetic acid & $1.07 \pm 0.24$ & $1.11 \pm 0.31$ & $1.15 \pm 0.38$ & $1.22 \pm 0.26$ \\
\hline & Propionic acid & $0.71 \pm 0.10$ & $0.70 \pm 0.17$ & $0.68 \pm 0.24$ & $0.70 \pm 0.10$ \\
\hline & Butyric acid & $0.40 \pm 0.10$ & $0.39 \pm 0.19$ & $0.38 \pm 0.13$ & $0.35 \pm 0.15$ \\
\hline
\end{tabular}

PTG, propionyl triglyceride. Each value represents as the means $\pm \mathrm{SD}, n=5$. Values having the different superscript letters within rows are significantly different, $p<0.05$.

これらの結果から,PTG を飼料などに多量添加する場 合, PTG の風味が問題である。また, PTGの消化吸収 性と消化管内の遊離プロピオン酸の残存性について検討 する必要がある。

\section{要 約}

プロピオン酸トリグリセリド $(\mathrm{PTG}) 1 ， 3 ， 5 \%$ 添加飼 料でラットを 14 日間飼育し, 血清, 肝蔵および賞の各脂 質含量,ならびに䔬と盲腸内容物の有機酸含量を調べた。

1） ラットの体重増加は, $5 \%$ PTG 群が最も低値を示 したが，食餉効率は各群間で差がなかった。

2） PTG 群の血清総コレステロール濃度は対照群よ り低かった。また, PTG 群の血清トリグリセリド濃度 は, 対照群に比較して低かったが，1\%および3\% PTG 添加群では有意差はなく, $5 \%$ PTG のみで有意に低かっ た。HDL-コレステロール濃度は各群でほとんど差がな かった。

3） 5\% PTG 群における肝の全脂質, 総コレステロー ルおよびトリグリセリド含量は，いずれも対照群より有 意に低かった。しかし, リン脂質の平均含量はいずれも 対照群より高值を示した。

4） $1 \%$ および $3 \%$ PTG 群における基の全脂質排泄量 は対照群より高値であった。しかし，5\% PTG 群は対照 群より低值を示した。また，中性ステロール排泄量は， いずれの PTG 群も対照群より高值であった。

5）䔬および盲腸内容物中の酢酸，プロピオン酸およ び酪酸含量は各群でほとんど差が認められなかったが, 䔬中の乳酸含量はPTG 含量の高い群ほど低値を示し
た。

\section{文献}

1）坂田 隆：化学と生物, 32, 23 (1994)

2) Chen, W.-J.L., Anderson, J.W. and Jennings, D. : Proc. Soc. Exp. Biol. Med., 175, 215 (1984)

3) Thacker, P.A., Salomons, M.O., Aherne, F.X., Milligans, L.P. and Bowland, J.P. : Can. J. Anim. Sci., 61, 969 (1981)

4) Ebihara, K., Miyada, T. and Nakajima, A. : Nutr. Res., 13, 1305 (1993)

5) Wright, R.S., Anderson, J.W. and Bridges, S.R. : Proc. Soc. Exp. Biol. Med., 195, 26 (1990)

6) Levrat, M., Favier, M.-L., Moundras, C., Remesy, C., Demigne, C. and Morand, C.:J. Nutr., 124, 531 (1994)

7) Yajima, T. and Sakata, T. : Bifidobacteria Microflora, 6, 7 (1987)

8) Hume, M.E., Corrier, D.E., Ambrus, S., Hinton, A. and DeLoach, J.R. : Avian Dis., 37, 1051 (1993)

9) American Institute of Nutrition : J. Nutr., 107, 1340 (1977)

10) Folch, J., Lees, M. and Sloane-Stanley, G.H. : J. Biol. Chem., 226, 497 (1957)

11) Morishita, Y., Yamada, H., Shiiba, K., Kimura, N. and Taniguchi, H. : Bifidobacteria Microflora, 12, 19 (1993)

12) Kishimoto, Y., Wakabayashi, S. and Takeda, H. : J. Nutr. Sci. Vitaminol., 41, 73 (1995)

13）竹久文之：栄食誌， 45, 325 (1992)

14）小田泰士, 青江誠一郎, 真田宏夫, 綾部雄幸: 栄食誌, 46, 147 (1993)

15）佐藤伸一, 井本精一, 小島正明, 神 勝紀, 唐沢 豊 : 栄食誌，47, 227 (1994)

(1996 年 12 月 20 日受理) 